\title{
LONG TERM (1901-2016) TEMPERATURE BASED POTENTIAL EVAPOTRANSPIRATION AND ARIDITY INDEX ANALYSIS FOR LOWER EASTERN REGION OF KENYA
}

\author{
Peter Kinyae Musyimi ${ }^{(1,2)}$, Balázs Székely ${ }^{(1)}$ (D), Tamás Weidinger ${ }^{(3)}$ (iD) \\ ${ }^{(1)}$ Department of Geophysics and Space Science, \\ Eötvös Loránd University, H-1117, Budapest, Hungary \\ (2) Department of Humanities and Languages, Karatina University, Karatina, Kenya \\ (3) Department of Meteorology, Eötvös Loránd University, H-1117, Budapest, Hungary \\ e-mail: pemusyimi@gmail.com, balazs.szekely@ttk.elte.hu,weidi@caesar.elte.hu
}

\begin{abstract}
Climate change has caused unreliable precipitation $(P)$ and temperature $(T)$ changes influencing global, regional and local water availability, agricultural production hence food insecurity. Precipitation and temperature are key climatic parameters among others in estimating potential evapotranspiration (PET). The main goal of this paper was to estimate long term (1901-2016) potential evapotranspiration time series using seven temperature- and two temperature and terrestrial radiation-based methods and compare the values estimates within four counties of Kenya. Data was sought from the World Bank database constructed based on CRU TS (Climatic Research Unit Timeseries). The estimates were computed and Thornthwaite method was used as a reference in comparison with the other methods. The study established that Hamon III and Thornthwaite equations gave lower annual PET estimates than the other methods. For instance, in Makueni county, the two methods gave potential evapotranspiration estimates ranging from $899 \pm 49.6 \mathrm{~mm} / \mathrm{year}$ to $1131 \pm 49.6 \mathrm{~mm} /$ year and $918 \pm 76.3 \mathrm{~mm} /$ year to $1274 \pm 76.3 \mathrm{~mm} /$ year respectively for the whole time period. Jensen-Haise and McGuinness-Borden PET estimates were the highest ranging from $2782 \pm 119.9 \mathrm{~mm} /$ year to $3343 \pm 120.0 \mathrm{~mm} /$ year and $2040 \pm 70.7 \mathrm{~mm} /$ year to $2371 \pm 70.7 \mathrm{~mm} /$ year in Makueni, respectively. Thornthwaite method depicted an increasing linear trend in all stations. Further, the Aridity Index (in our case P/PET based on the Thornthwaite method) varied from one climatic period (30 years) to the other with a large range of 0.3 to 1.2 in Makueni county. The study also established that Kitui county had the highest estimate values of PET from all methods used. The study concludes that different temperature- and temperature and terrestrial radiation-based methods perform differently and give different PET estimation based on the parameter specific requirement. The study is suitable in selection and comparisons of best temperature-based, temperature and terrestrial radiation methods in PET estimation in the tropical, data scarce regions in Kenya.
\end{abstract}

\section{Introduction}

Potential evapotranspiration (PET) has varied scholarly definitions based on the context of use (Lakatos et al., 2020). For instance, Thornthwaite (1948) defined it 'as process of water transfer from soil to the atmosphere, either directly or indirectly or through plants where the water required for such processes is fully available'. Therefore, based on any definition, PET is a very crucial parameter in agriculture, hydrology, global, regional and local hydroclimatology. As stated by Ryu et al. (2020), evapotranspiration is an important component in water budget and its acceleration can lead to agricultural drought due to insufficient soil moisture content which varies depending on soil characteristics. Decreasing precipitation and 
increasing temperature more so in Arid and Semi-Arid lands (ASALs) leads to increased drought characteristics such as increased drought durations, frequencies and severity (Musyimi et al., 2018). Therefore, estimation of PET is important in solving challenges brought about by climate change and variability and understanding it, is a prerequisite in calculation of Aridity Index $(A I=P / P E T)$ that is of the average water available in the soil, defined as the ratio between mean annual precipitation $(P)$ and mean annual potential evapotranspiration (PET) in different parts of the world and formulation of appropriate policies in water and agricultural sectors (Xystrakis \& Matzarakis, 2011). More detailed PET estimation requires varied range of meteorological parameters such as air surface temperature, wind speed, sunshine, extra-terrestrial radiation, vapour pressure among other radiation components (Ryu et al., 2020; Trajkovic et al., 2020). The complex methods use almost all meteorological data. They include FAO Penman-Monteith (PM) as used by Allen et al. (1998), among others. Temperature-based methods have been used in regions of the world with different climate characteristics. For example, Jensen \& Haise (1963) were used in semiarid to arid climate of Western USA, while Hargreaves equation was used in semi-arid to arid climate of California (Samaras et al., 2014). This indicates that suitability and feasibility for application of simple PET equations differ significantly according to the diversity of climatic regions (Tukimat et al., 2012).

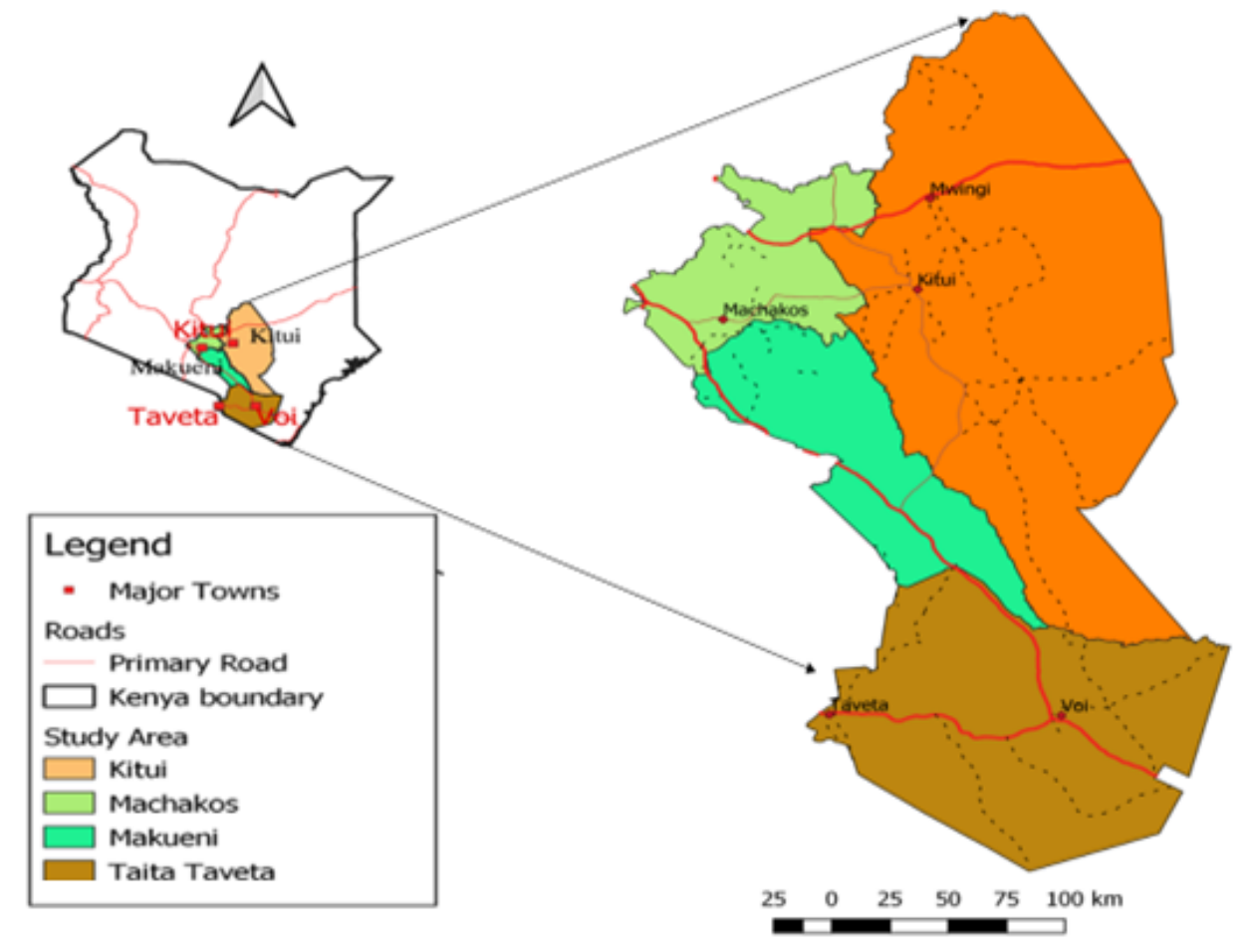

Figure 1: Map of Kenya showing study area, four selected counties.

In Kenya, where agriculture is the mainstay of economy and with diverse climatic regions PET estimation is of key importance. This is because, as suggested by Shilenje et al. (2015), agriculture is rain-fed and depends purely on precipitation as a major weather variable. Therefore, this calls for relevant studies on how suitable temperature-based or/and temperature and terrestrial radiation-methods are in estimating of PET. Various methods have been used in few studies in some counties in Kenya, for instance Penman-Monteith (PM) in Muranga county, (Shilenje et al., 2015) and in Lake Victoria Basin (Chumo et al., 2011). 
The main objectives of this study are to estimate i) long term (1901-2016) time series of potential evapotranspiration (Table 1) and Aridity Index (P/PET), ii) investigate the temperature and precipitation trends in the four lower eastern counties of Kenya for a period (1901-2016).

Table 1: Methods for calculation of monthly potential evaporation $\left(\mathrm{PET}_{\mathrm{i}}\right)$.

\begin{tabular}{|l|l|}
\hline Name of the method (citation) & \multicolumn{1}{|c|}{ Formulae PET $($ mm/month) } \\
\hline \multicolumn{1}{|c|}{ Temperature based methods } \\
\hline Thornthwaite (Thornthwaite, 1948) & $P E T_{i}=16 \cdot\left(\frac{L}{12}\right) \cdot\left(\frac{N}{30}\right) \cdot\left(\frac{10 T_{i}}{I}\right)^{\alpha}$ \\
\hline Blanney-Criddle (Blaney \& Criddle, 1950) & $P E T_{i}=p \cdot\left(0.46 \cdot T_{i}+8\right)$ \\
\hline Hamon Basic. (Hamon, 1963) & $P E T_{i}=29.8 \cdot H r_{d a y} \cdot e_{s a t} \cdot \frac{T_{i}}{T_{i}+273.2}$ \\
\hline Hamon I (Lu et al., 2005) & $P E T_{i}=0.1651 \cdot \frac{L}{12} \cdot\left[\frac{216.7 \cdot e_{s}}{T_{i}+273.2}\right] \cdot \alpha$ \\
\hline Hamon II (Oudin et al., 2005) & $P E T_{i}=\left(\frac{L}{12}\right)^{2} \cdot \operatorname{Exp}\left(\frac{T_{i}}{16}\right)$ \\
\hline Hamon III (Rosenberry et al., 2004) & $P E T_{i}=0.55 \cdot\left(\frac{L}{12}\right)^{2} \cdot\left(\frac{S V D}{100}\right) \cdot 25.4$ \\
\hline McClouds (Irmak et al., 2003) & $P E T_{i}=a \cdot b \cdot\left(T_{i}-32\right)$ \\
\hline Temperature and terrestrial radiation-based methods \\
\hline McGuinnes Bordne's (Oudin et al., 2005) & $P E T_{i}=\left(\frac{R_{e}}{\lambda \cdot \rho}\right)^{2} \cdot \frac{T_{i}+5}{68}$ \\
\hline Jensen and Haise (Jensen \& Haise, 1963) & $P E T_{i}=\frac{R_{e}}{\lambda \cdot \rho} \cdot \frac{T_{i}}{40}$ \\
\hline
\end{tabular}

$L$ - day length (hours), $N$ - number of days in the given month, $I$ - annual heat index, $\alpha$ - temperature dependent exponent (see, Ács et al., 2007), $T_{i}$-monthly mean temperature $\left({ }^{\circ} \mathrm{C}\right), \mathrm{p}$ - mean daily percentage of annual daytime hours $(\%), e_{s a t}$ - saturation water vapour pressure $(\mathrm{kPa})$, $S V D$ - saturated vapour density at mean $T_{i}$ temperature $\left(\mathrm{g} \mathrm{m}^{-3}\right), R_{e}$ - extraterrestrial radiation $\left(\mathrm{MJ} \mathrm{m}^{-2}\right.$ day $^{-1}$ ) from Allen et al. (1998), $a=0.01$ and $b=1.07$ - constants, $\rho_{w}$ - water density $\left(1000 \mathrm{~kg} / \mathrm{m}^{3}\right), \lambda$ - latent heat of vaporization $(\mathrm{MJ} / \mathrm{kg}), H r_{d a y}$ - the number of daylight hours.

\section{Geography and Climate of Kenya}

Kenya is located along the equator in Eastern Africa (Fig. 1). It lies in latitude $5^{\circ} \mathrm{N}, 5^{\circ} \mathrm{S}$ and longitude $34^{\circ} \mathrm{E}, 42^{\circ} \mathrm{E}$. It has an area of $582,646 \mathrm{~km}^{2}$ with a population of $47,564,296$ million people (KNBS, 2019) and 47 counties. The rainfall pattern and distribution in Kenya depicts bimodal characteristic. The short rainy season occurs between October November and December (OND). This is majorly influenced by the (ITCZ) Intertropical Convergence Zone while the long rainy season occurs between March, April and May (MAM) and it is mostly under influence from southeast trade winds and the Indian Monsoon winds (Marshall et al., 2012). The mean annual precipitation is $669 \mathrm{~mm}$, and mean annual temperature is $24.3{ }^{\circ} \mathrm{C}$ (CCKP, 2020). Due to climate change, Kenya has faced various extreme events, which include droughts, floods, landslides, mudslides, forests fires, which has led to death and 
displacement of people, epidemics, destruction of property, loss of forested land (Huho et al., 2016).

\section{Investigated Area, Dataset}

The investigated area was Lower Eastern Kenya. It comprises of Makueni, Machakos, Kitui and Taita-Taveta Counties (Fig. 1). Makueni County is arid and semi-arid, characterized by severe water scarcity, food insecurity and low adaptive capacity and resilience to climate change and variability (Muema et al., 2018). Rainfall ranges from 800-1200 $\mathrm{mm}$ while the low-lying areas receive at range of $150-650 \mathrm{~mm}$ per year. Kitui County is located on latitude $0^{\circ} 10^{\prime}$ and $3^{\circ} 0^{\prime}$ South and Longitude $37^{\circ} 50^{\prime}$ and $39^{\circ} 0^{\prime}$ East. It is also a semi-arid characterized by unreliable and poorly distributed rainfall with altitude ranging from $400 \mathrm{~m}$ and $1830 \mathrm{~m}$ above sea level (Khisa, 2018). Machakos County still falls under arid and semiarid climate, with elevation ranging from $400 \mathrm{~m}$ to $2100 \mathrm{~m}$ above sea level (Huho, 2017). Taita-Taveta County is semi-humid to semi-arid with mean annual rainfall of $650 \mathrm{~mm}$ and average temperatures of $23{ }^{\circ} \mathrm{C}$ (GOK, 2013). Data sets in the stations mentioned comprised of monthly precipitation and temperature over a period of 116 years (1901-2016) and it was sought from CCKP (2020). This data set is constructed based on global available observational datasets derived from the Climate Research Unit Time series (CRU-TS).

\section{Methodology}

Data was analysed using Visual Basic Macro programmes developed in MS Excel. Similar programming method has also been applied by Sellinger (1996) in estimation of evapotranspiration using Thornthwaite method. Monthly PET values were calculated from 7 temperature based and 2 temperature and terrestrial radiation-based methods presented in Table 1 . The methods were purposively selected based on the appropriateness of the variables in the datasets. Thornthwaite equation was used in the study as a reference formula. This was because it is and has widely been used in the computation of potential evapotranspiration by many scientists and used as a benchmark for the other methods.

\section{Results and Discussions}

This section describes trend analysis of temperature and precipitation, compares precipitation and potential evapotranspiration using various methods and examines mean standard deviation of temperature, precipitation, potential evapotranspiration and Aridity Index $(P / P E T)$.

\subsection{Trend analysis: Annual Temperature and Precipitation}

Temperature and precipitation data for 116 years (1901-2016) was analysed first. The annual temperature decreases for the first two decades in the $20^{\text {th }}$ century after that an increase in the last decade in the climatic period of 1910-1930. Middle of 1920's years had similar annual temperatures as in the present. End of the 1920s there was a dramatical decrease of the annual temperatures which was similar to the $2^{\text {nd }}$ decades of the $20^{\text {th }}$ century. The reason of large temperature fluctuation is not well known. From that time forth, the annual temperature increased (Fig. 2). The trend lines show that temperature is gradually increasing over the climatic periods except the third decade of the $20^{\text {th }}$ century. The trend value was $1.9{ }^{\circ} \mathrm{C} / 100$ year of the entire period (1901-2016). This tendency conforms but underestimated by AR4, 
AR5 assessment reports and IPCC (2014) which indicate that temperature will increase globally $0.074{ }^{\circ} \mathrm{C}$ per decade for 100 years.

Contrary to the decrease in temperature in the first 20 years in the first climatic period of the analysis (1901-1930), precipitation analysis shows a variability from year to year in the four Counties. Results show increasing trend in the climatic period of 1960-1990. However, the last climatic period (1991-2016) indicates a decreasing trend (trend line) of precipitation (Fig. 2). The slightly decreasing trend value was $-52 \mathrm{~mm} / 100$-year of the entire period. The absolute maximum annual precipitation for the stations were $1383 \mathrm{~mm}, 1209 \mathrm{~mm}, 1296 \mathrm{~mm}$ and $1203 \mathrm{~mm}$ for Kitui, Makueni, Voi and Machakos, respectively, while the absolute minimum annual precipitation was $364 \mathrm{~mm}, 326 \mathrm{~mm}, 388 \mathrm{~mm}$ and $340 \mathrm{~mm}$ for Kitui, Makueni, Voi and Machakos, respectively. This conforms to the results of Huho (2017) who suggests that the amount of rainfall received in a given region differs from year-to-year. Consequently, higher variability dominates the arid and semi-arid climatic regions, which are characterised by low, unreliable and erratic rainfall amounts.
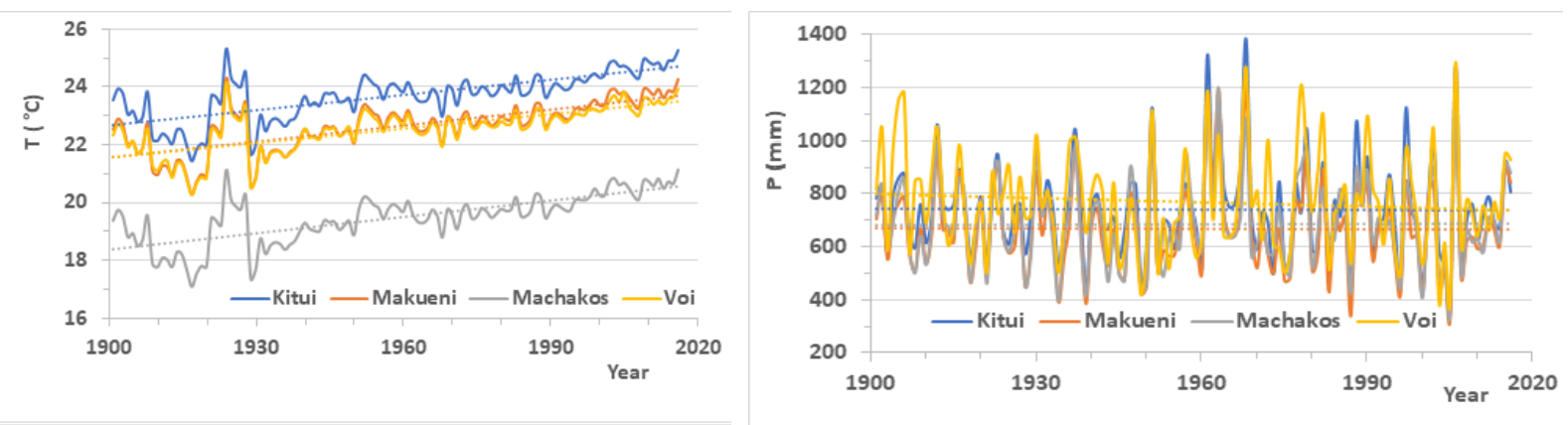

Figure 2: Long term trend (1901-2016) of annual temperatures (left) and precipitation (right) in four Counties of Kenya (CRU TS grid points close to Kitui, Makueni, Machakos and Voi).

\subsection{Potential Evapotranspiration Estimations}

Potential evapotranspiration (PET) was estimated using seven temperature- and two temperature/terrestrial radiation-based equations (Fig. 3). These methods are widely and continuously applied, because temperature records are largely available climatic data for computation of PET (Shuttleworth, 1993). Results show that Hamon III and Thornthwaite equations give the lowest values for instance in Makueni County PET estimates ranged from $899 \mathrm{~mm} /$ year to $1132 \mathrm{~mm} /$ year and $918 \mathrm{~mm} /$ year to $1273 \mathrm{~mm} /$ year respectively. The methods are applied in computation of PET because they primarily rely on temperature as a parameter according to Shaw et al. (2011). This finding conforms with a study carried out by Tukimat et al. (2012) who found that PET in Muda Irrigation Scheme in Malaysia ranged from $1360 \mathrm{~mm} /$ year to $1490 \mathrm{~mm} /$ year.

Using Makueni County as a reference, Jensen-Haise and McGuinness equations gave the highest value estimates of potential evapotranspiration ranging from $2782 \mathrm{~mm} /$ year to $3343 \mathrm{~mm} /$ year and $2371 \mathrm{~mm} /$ year to $2040 \mathrm{~mm} /$ year, respectively. The highest values of potential evapotranspiration estimate in the Jensen-Haise and McGuinness-Borden methods were attributed to the inclusion of extra-terrestrial radiation variable in computation. The PET values are also very high, because the climate of the four Counties is arid and semiarid. This conforms with a study by Shilenje et al. (2015) who stated that PET is higher in the equatorial and tropical regions and depends moisture availability content and its variability is affected by diversity of variations of parameters and conditions of meteorological stations.

Kitui had the highest estimate values of PET for the nine methods. These high values were attributed to higher temperatures in Kitui. This conforms with Fisher et al. (2011), who stated 
that the PET values vary from region to region, varied ecosystems and different climates, for instance, $P E T$ values of the Sahara Desert are quite higher than Tundra because it is hotter than Tundra. Further, comparison of Q2 (Median) among the four stations and the nine methods were carried out. It was evident that Hamon III method had the lowest Q2 value of $1031 \mathrm{~mm} /$ year in Makueni, $1027 \mathrm{~mm} /$ year in Voi, $1095 \mathrm{~mm} /$ year in Kitui and $859 \mathrm{~mm} /$ year in Machakos. It was closely followed by the Thornthwaite method, which registered $1100 \mathrm{~mm} /$ year in Makueni, $1093 \mathrm{~mm} /$ year in Voi, $1209 \mathrm{~mm} /$ year in Kitui, and $876 \mathrm{~mm} /$ year in Machakos.

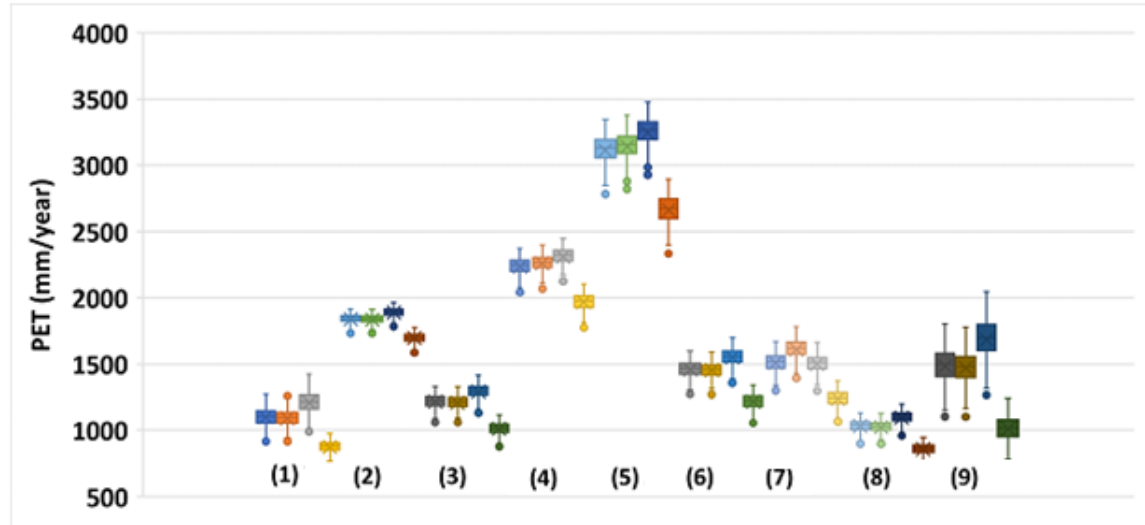

(1) Thornthwaite, (2) Blanney-Criddle, (3) Hamon Basic, (4) McGuinness- Borden,

(5) Jensen-Haise, (6) Hamon I, (7) Hamon II, (8) Hamon III, (9) McCloud

Figure 3: Box plot and whiskers for temperature $\left({ }^{\circ} \mathrm{C}\right)$ and both temperature and temperature and terrestrial radiation-based methods in the four stations of the four Counties of Kenya represented with CRU grid points close to Kitui (first), Makueni, Machakos and Voi (last).

In this study, Thornthwaite method was used as the reference method. In relation to the trend of PET, Makueni County was used as the reference because its centrally located between Kitui, Machakos and Voi in Taita-Taveta County (Fig. 4). Out of the four Counties Thornthwaite and Hamon III methods showed the lowest estimates as compared with the other methods. This conforms with the study by Lang et al. (2017) in Southwestern China. Long term variations of time series of PET naturally are similar with temperature time series (compare Figs. 2 and 4).

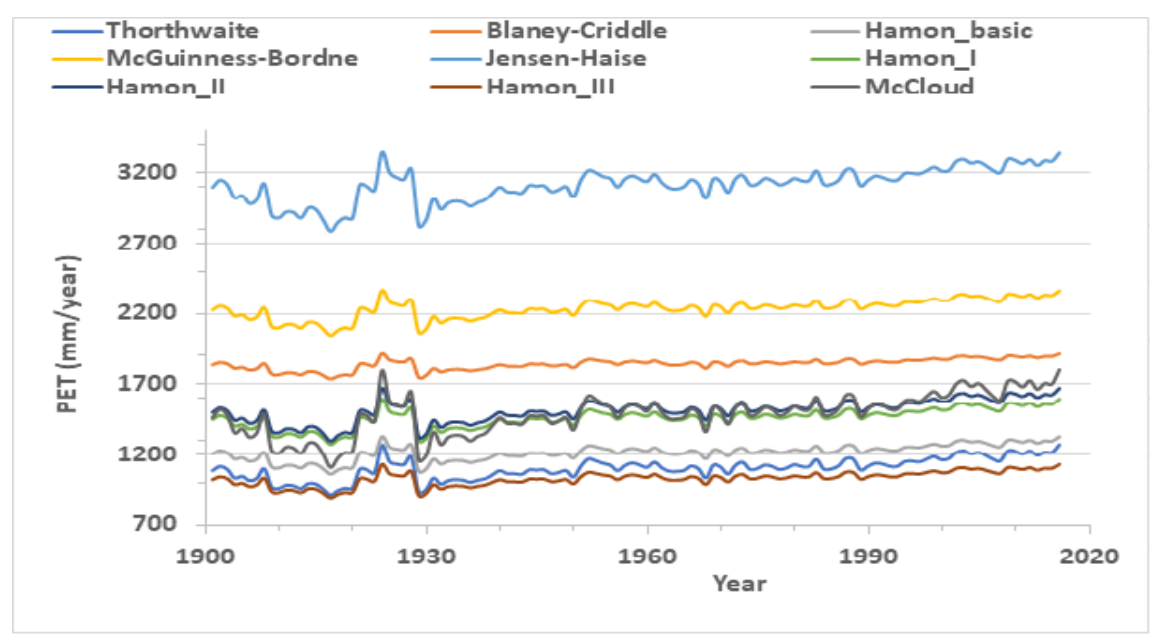

Figure 4: Trends of the temperature- and both temperature and terrestrial radiation-based potential evapotranspiration methods in Makueni County. 
5.3. Comparison of $P E T$ and $P$ ( $\mathrm{mm} / \mathrm{year}$ ) from whole period, last climatic period (1991-2016) and using 1961-1990 as a reference climatic period in Makueni County

Comparisons between Precipitation $(P)$ and PET values were also analysed using Thornthwaite method. Analysis shows that PET in $\mathrm{mm} /$ year estimates were higher than the annual precipitation in Makueni County (Fig. 5). Using climatic period from 1961-1990 it was evident that last period (1991-2016) had high PET values ranging from $1152 \mathrm{~mm} / \mathrm{year}$ to $1218 \mathrm{~mm} /$ year compared with the entire period (1901-2016) which had a range from $1150 \mathrm{~mm} /$ year to $1058 \mathrm{~mm} /$ year. The reference period PET values ranged from $1095 \mathrm{~mm} /$ year to $1124 \mathrm{~mm} /$ year. PET Q2 was also the highest with a value of $1187 \mathrm{~mm} / \mathrm{year}$ in the last period as compared to the reference $(1111 \mathrm{~mm} /$ year $)$ and entire period $(1105 \mathrm{~mm} /$ year $)$. Precipitation is slightly low in the entire period with Q2 of $654 \mathrm{~mm}$ as compared to the reference period which has $706 \mathrm{~mm}$ while the last period has a Q2 value of $637 \mathrm{~mm} /$ year.

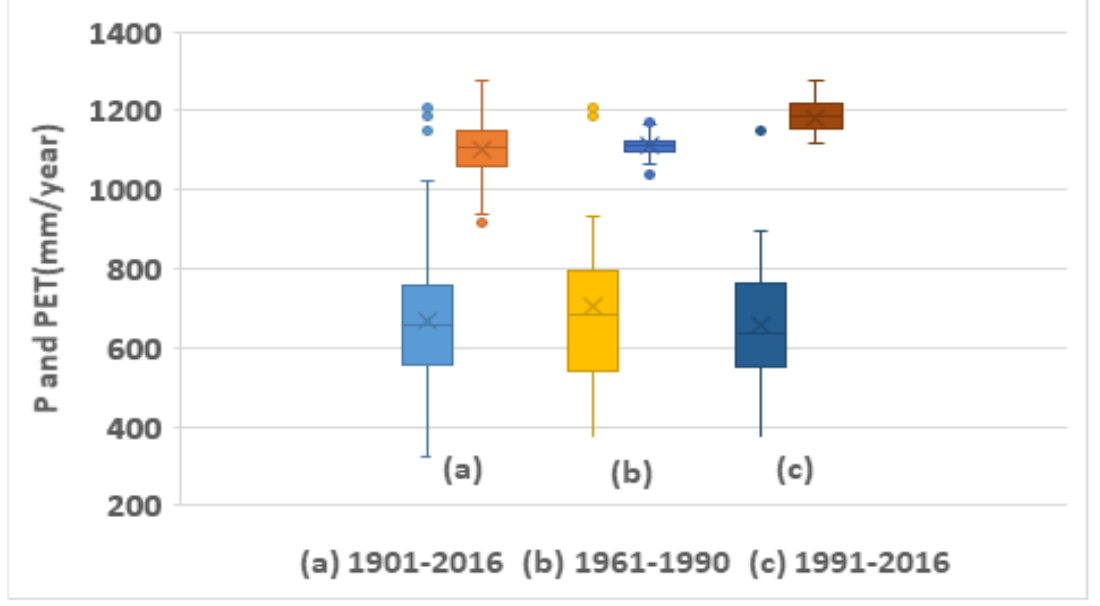

Figure 5: Box plot and whiskers comparing PET and $\mathrm{P}(\mathrm{mm} / \mathrm{year})$ from whole period, last climatic period (1991-2016) and using 1961-1990 as a reference in Makueni County.

The interquartile range was high in the reference period with a value of $251 \mathrm{~mm} / \mathrm{year}$ as compared to the last and the entire period which had values of $210 \mathrm{~mm} /$ year and $202 \mathrm{~mm} /$ year respectively. PET Interquartile range was the lowest at the reference period with a value of $29 \mathrm{~mm} /$ year as compared to the last and entire period of study which depicted values of $66 \mathrm{~mm} /$ year and $100 \mathrm{~mm} /$ year, respectively

\subsection{Mean and standard deviation of annual temperature $(T)$, precipitation $(P), P E T$ and Aridity Index $(A I)$ in Makueni County}

Analysis based on standard deviation $(\sigma)$ from the mean was carried out at an interval of a decade (10 years) and maintained the 30 years climate normal period as recommended by World Meteorological organisation (Table 2).

Results show that for temperature, deviation from the mean of $22.6{ }^{\circ} \mathrm{C}$ decreased for the first five climatic periods, remained constant for the three climatic periods and slightly increased in the last two climatic periods. Using 1961-1990 as the reference period, analysis shows that annual mean and standard deviation of temperature $(T)$ and PET decreased slightly before the reference period and increased slightly after that period. $\overline{A I}$ decreased and remained constant with a value of 0.55 after the reference period, while $\sigma_{A I}$ increased slightly until the reference period and depicted variability after the period. In relation precipitation, 
deviation increased slightly for the first seven climatic periods until 1961-1990 and decreased slightly for the last climatic periods. Based on Aridity Index, the quotient of $(P / P E T)$ the analysis revealed that there was a slight variation for the four climatic periods. For instance, from 1901-1930 AI (Aridity Index) ranged from 0.4-1.0, 1931-1960 range was from 0.4 to $1.0,1961-1990$ the values ranged from $0.3-1.2$ and from 1990-2016 the range was from 0.3-1.0. This implies that there was variation in aridity values in the four climatic periods and the aridity ranges from being semi-arid $(0.2-0.5)$ to humid $(>0.65)$ according to global aridity values classification (Middleton \& Thomas, 1997).

Table 2: Mean and standard deviation of annual average temperature $(\mathrm{T})$, precipitation $(\mathrm{P})$, PET and Aridity Index (AI) in Makueni County.

\begin{tabular}{|c|c|c|c|c|c|c|c|c|c|c|}
\hline $\begin{array}{l}\text { Mean }(\bar{x}) \text { and } \\
\text { Standard } \\
\text { Deviation }\left(\sigma_{X}\right)\end{array}$ & $\begin{array}{l}1901- \\
1930\end{array}$ & $\begin{array}{l}1911- \\
1940\end{array}$ & $\begin{array}{l}1921- \\
1950\end{array}$ & $\begin{array}{l}1931- \\
1960\end{array}$ & $\begin{array}{l}1941- \\
1970\end{array}$ & $\begin{array}{l}1951- \\
1980\end{array}$ & $\begin{array}{l}1961- \\
1990\end{array}$ & $\begin{array}{l}1971- \\
2000\end{array}$ & $\begin{array}{l}1981- \\
2011\end{array}$ & $\begin{array}{l}1987- \\
2016\end{array}$ \\
\hline $\bar{T} \quad\left({ }^{\circ} \mathrm{C}\right)$ & 21.9 & 21.8 & 22.3 & 22.4 & 22.7 & 22.8 & 22.8 & 23 & 23.3 & 23.5 \\
\hline$\sigma_{T}\left({ }^{\circ} \mathrm{C}\right)$ & 1.0 & 0.9 & 0.7 & 0.5 & 0.4 & 0.3 & 0.3 & 0.3 & 0.4 & 0.4 \\
\hline $\bar{P} \quad(\mathrm{~mm})$ & 675 & 671 & 636 & 636 & 650 & 694 & 706 & 693 & 641 & 653 \\
\hline$\sigma_{P}(\mathrm{~mm})$ & 134 & 154 & 154 & 155 & 214 & 211 & 215 & 154 & 183 & 181 \\
\hline$\overline{P E T}(\mathrm{~mm})$ & 1038 & 1032 & 1067 & 1077 & 1100 & 1112 & 1111 & 1128 & 1159 & 1179 \\
\hline$\sigma_{P E T}(\mathrm{~mm})$ & 85.5 & 81.4 & 65.8 & 47.3 & 32.9 & 28.1 & 29.6 & 29.6 & 41.8 & 43.0 \\
\hline$\overline{A I}(-)$ & 0.66 & 0.66 & 0.60 & 0.59 & 0.63 & 0.64 & 0.64 & 0.57 & 0.55 & 0.55 \\
\hline$\sigma_{A I}(-)$ & 0.15 & 0.17 & 0.16 & 0.16 & 0.20 & 0.20 & 0.20 & 0.13 & 0.16 & 0.15 \\
\hline
\end{tabular}

\section{Conclusions}

In this paper we investigated long term (1901-2016) time series of temperature $(T)$, precipitation $(P)$, potential evapotranspiration $(P E T)$ and Aridity Index $(P / P E T)$. It was established that

- Different temperature-based methods performed differently and gave different $P E T$ estimation in the four Counties with Hamon III and Thornthwaite equations depicting the least values. For instance, using climatic period from 1961-1990 as the reference, it was evident from the analysis that last period (1991-2016) had high Thornthwaite PET values ranging from $1152 \mathrm{~mm} /$ year to $1218 \mathrm{~mm} /$ year compared with the entire period (1901-2016) which had a range from $1150 \mathrm{~mm} /$ year to $1058 \mathrm{~mm} /$ year.

- Temperature trend analysis value was $1.9^{\circ} \mathrm{C} / 100$-year, while precipitation trend value was $-52 \mathrm{~mm} / 100$-year in the study area.

- Aridity Index $\overline{A I}$ decreased slightly until the reference period (1960-1990) and remained constant with a value of 0.55 after the reference period, while $\sigma_{A I}$ increased slightly until the reference period and depicted variability after the period.

The study concludes that these results are important to water resource management authorities at the four Counties and the other County governments and national government in Kenya, researchers in scarce data regions, development partners in water agencies and institutions, planners and policy makers at every level of government. The next step of the investigation will be the construction of 1D evapotranspiration model in monthly scale using the soil characteristics based on the methodology of Sellinger (1996) and Ács et al. (2007). 
Musyimi, P.K., Székely, B., Weidinger, T.: Long term (1901-2016) temperature based potential evapotranspiration and aridity index analysis for lower eastern region of Kenya

\section{References}

Ács, F., Breuer, H., Szász, G., 2007: A tényleges párolgás és a talaj vízkészlet becslése tenyészidőszakban. Agrokémia és Talajtan, 56: 217-236. https://doi.org/10.1556/Agrokem.56.2007.2.3

Allen, R.G., Pereira, L.S., Raes, D., Smith, M., 1998: Crop evapotranspiration: FAO Irrigation and drainage paper 56. FAO - Food and Agriculture Organization of the United Nations Rome, Italy

Blaney, H.F., Criddle, W.D., 1950: Determining Water Requirements in Irrigated Areas from Climatologically and Irrigation Data. USDA (SCS) TP 9648

CCKP (Climate Change Knowledge Portal), 2020: Kenya Projected Future Climate. https://climateknowledgeportal. worldbank.org/country/kenya/climate-data-projections)

Chumo, K.J., Sharma, C.T., Ng'etich, W., 2011: Estimating potential evapotranspiration of a data scarce region: a case of Lake Victoria Basin of Kenya. International Journal of Current Research, 3: 393-399.

Fisher, J.B., Whittaker, J.R., Malhi, Y., 2011: ET.come home: Potential evapotranspiration in geographical ecology. Global Ecology and Biogeography, 20: 1-18. https://doi.org/10.1111/j.14668238.2010. 00578.x

$G O K, 2013$ : National climate change action plan 2013-2017, Nairobi, Ministry of Environment and Natural resources. 258 p. https://cdkn.org/wp-content/uploads/2013/03/Kenya-National-ClimateChange-Action-Plan.pdf

Hamon, W.R., 1963: Computation of direct runoff amounts from storm rainfall. International Association of Scientific Hydrology Publ., 63: 52-62.

Huho, J.M., 2017: An analysis of rainfall characteristics in Machakos County, Kenya. IOSR Journal of Environmental Science, Toxicology and Food Technology, 11(4): 64-72. https://doi.org/10.9790/2402-1104026472

Huho, J.M., Mashara J.N, Musyimi P.K., 2016: Profiling Disasters in Kenya and their causes. Academic Research International Journal, 7(1): 290-305.

IPCC, 2014: Climate Change 2014: Synthesis Report. Contribution of Working Groups I, II and III to the Fifth Assessment Report of the Intergovernmental Panel on Climate Change [Core Writing Team, R.K. Pachauri and L.A. Meyer (eds.)]. IPCC, Geneva, Switzerland, 151p.

Irmak, S., Irmak, A., Allen, R.,Jones, J., 2003: Solar and Net Radiation-Based Equations to Estimate Reference Evapotranspiration in Humid Climates. Journal of Irrigation and Drainage Engineering, 129(5): 336-347. https://doi.org/10.1061/(ASCE)0733-9437(2003)129:5(336)

Jensen, M.E., Haise, H.R., 1963: Estimating evapotranspiration from solar radiation. Journal of Irrigation Drainage Engineering, 89: 15-41. https://doi.org/10.1061/JRCEA4.0000287

KNBS (Kenya National Bureau of Statistics), 2019: 2019 Kenya Population and Housing Census. Volume IV: Distribution of Population by Socio-Economic Characteristics. December 2019. Accessed from https://www.knbs.or.ke/?wpdmpro=2019-kenya-population-and-housing-censusvolume-iv-distribution-of-population-by-socio-economic-characteristics

Khisa, G.V., 2018: People's perception on climate change and its effects on livelihood in Kitui County. International Journal of Development and Sustainability, 7(1): 70-81.

Lakatos, M., Weidinger, T., Hoffmann, L., Bihari, Z., Horváth, Á., 2020: Computation of daily Penman-Monteith reference evapotranspiration in the Carpathian Region and comparison with Thornthwaite estimates. Advances in Science and Research, 16: 251-259. https://doi.org/10.5194/asr-16-251-2020

Lang., D., Zheng, J., Shi, J., Liao F, Ma, X., Wang, W., Chen, X., Zhang., M., 2017: A Comparative Study of Potential Evapotranspiration Estimation by Eight Methods with FAO Penman-Monteith Method in Southwestern China. Water, 9: 734. https://doi.org/10.3390/w9100734.

Lu, J.B., Sun, G., McNulty, S.G., Amatya, D.M. 2005: A comparison of six potential evapotranspiration methods for regional use in the southeastern United States. Journal Amazon Water Resources Association, 41(3): 621-633. https://doi.org/10.1111/j.1752-1688.2005.tb03759.x

Marshall, M.T., Funk, C., Michaelsen, J., 2012: Agricultural Drought Monitoring in Kenya Using Evapotranspiration Derived from Remote Sensing and Reanalysis Data. USGS Staff -- Published Research. 978. http://digitalcommons.unl.edu/usgsstaffpub/978 
Musyimi, P.K., Székely, B., Weidinger, T.: Long term (1901-2016) temperature based potential evapotranspiration and aridity index analysis for lower eastern region of Kenya

Middleton, N., Thomas, D. (eds.), 1997: World atlas of desertification 2ED. UNEP (United Nations Environment Programme) UNEP (017)/W927, London, New York, Sydney, Auckland, Arnold, UNEP. 182p.

Musyimi, P.K, Huho, J.M., Opiyo, F.E., 2018: Understanding Drought Characteristics and Perceived Effects on Water Sources in Kenya's Drylands: A Case Study of Makindu Sub-County. In Fymat A.L. and Kapalanga, J. (eds) Advancing Africa's Sustainable Development: Proceedings of the 4th Conference on Science Advancement. Cambridge Scholars Publishing, Newcastle upon Tyne, UK. 324-349.

Muema, E., Mburu, J., Coulibaly, J., Mutune, J., 2018: Determinants of access and utilisation of seasonal climate information services among smallholder farmers in Makueni County, Kenya. Heliyon, 4(11): e00889. https://doi.org/10.1016/j.heliyon.2018.e00889

Oudin, L., Hervieu, F., Michel, C., Perrin, C., Andréassian, V., Anctil, F., Loumagne, F., 2005: Which potential evapotranspiration input for a lumped rainfall-runoff model? Part 2-Towards a simple and efficient potential evapotranspiration model for rainfall-runoff modelling. Journal of Hydrology, 303: 290-306. https://doi.org/10.1016/j.jhydrol.2004.08.026

Rosenberry, D., Stannard, D., Winter, T., Martinez, M., 2004: Comparison of 13 equations for determining evapotranspiration from a prairie wetland, Cottonwood Lake Area, North Dakota, USA. Wetlands, 24(3): 483-497. https://doi.org/10.1672/0277-5212(2004)024[0483:COEFDE]2.0.CO;2

Ryu, Y., Chung, E., Seo, B.S., Sung, H.J., 2020: Projection of Potential Evapotranspiration for North Korea Based on Selected GCMs by TOPSIS. KSCE Journal of Civil Engineering, 24(9): 2849-2859. https://doi.org/10.1007/s12205-020-0283-z

Samaras, D., Reif, A., Theodoropoulos, K., 2014: Evaluation of Radiation-Based Reference Evapotranspiration Models Under Different Mediterranean Climates in Central Greece. Water Resources Management, 28: 207-225. https://doi.org/10.1007/s11269-013-0480-3

Sellinger, E.C., 1996: Computer program for estimating evapotranspiration using the Thornthwaite method. NOAA Technical Memorandum ERL GLERL-101, Great Lakes Environmental Research Laboratory, Ann Arbor, MI, USA.

Shaw, B.S., Susan, J., Riha, J.S., 2011: Assessing Temperature-Based PET Equations under a Changing Climate in Temperate, Deciduous Forests. Hydrological Processes, 25: 1466-1478. https://doi.org/10.1002/hyp.7913

Shilenje, Z.W., Murage, P., Ongoma,V., 2015: Estimation of Potential Evaporation Based on Penman Equation under Varying Climate, for Murang'a County, Kenya. Pakistan Journal of Meteorology, 12(23): 33-42.

Shuttleworth, W.J., 1993: Evaporation. In: Handbook of Hydrology. Chapter 4, Maidment D.R. (ed.). McGraw-Hill: New York.

Trajkovic, S., Gocic, M., Pongracz, R., Bartholy, J., Milanovic, M., 2020: Assessment of Reference Evapotranspiration by regionally calibrated Temperature based equations. Journal of Civil Engineering, 24(3): 1020-1027. https://doi.org/10.1007/s12205-020-1698-2

Thornthwaite, C.W., 1948: An approach toward a rational classification of climate. Geographical Review, 38: 55-94. https://doi.org/10.2307/210739

Tukimat, A.N.N., Harun, S., Shahid, S., 2012: Comparison of different methods in estimating potential evapotranspiration at Muda Irrigation Scheme of Malaysia. Journal of Agriculture and Rural Development in the Tropics and Subtropics, 113(1): 77-85.

Xystrakis, F., Matzarakis, A., 2011: Evaluation of thirteen empirical potential evapotranspiration equations (PETref) in the island of Crete, southern Greece. Journal of Irrigation and Drainage Engineering, 137(4): 211-233. https://doi.org/10.1061/(ASCE)IR.1943-4774.0000283

\section{ORCID}

Székely B. (D) https://orcid.org/0000-0002-6552-4329

Weidinger T. (iD https://orcid.org/0000-0001-7500-6579 